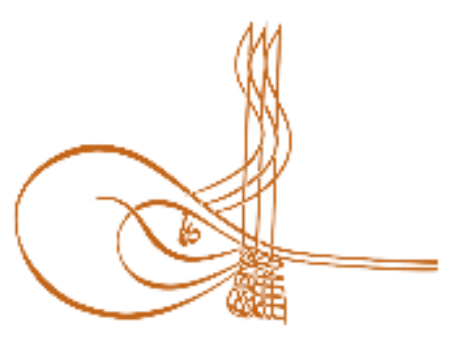

www.turkishstudies.net/turkishstudies
Turkish Studies

eISSN: $1308-2140$

Research Article / Araştırma Makalesi

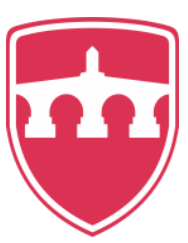

INTERNATIONAL

BALKAN

UNIVERSITY

Sponsored by IBU

\title{
Reflecting Team Experiences of Clients During the Counseling Process: A Post-Modernist Study*
}

\author{
Psikolojik Danışma Sürecinde Danışanların Yansıtıcı Ekip Sürecine İlişkin Deneyimleri: Post- \\ modernist Bir Çalışma
}

\author{
Sümbül Yalnızca Yıldırım ${ }^{* *}$ - Ayça Saraç Dengiz ${ }^{* * *}$ - Erdinç Çağlayan ${ }^{* * * *}$
}

\begin{abstract}
Reflecting team practice first emerged as a technique that was used to strengthen the therapeutic process in family and couple therapies but later, it began to be used as a supervision method. This practice, which is nowadays used in both forms, is applied in the form of an inclusion of one or more therapists except for the therapist in the counseling process and a conversation of those people about the dialogue between the client/family and the therapist in a therapeutic setting the effects of reflecting team practice in the supervision process and in the therapeutic process have been discussed in many studies. However, there are few empirical studies on the effectiveness of the reflecting team in the counseling process. It is considered that this study examining the effect of reflecting team practice on the counseling process from the client's perspective will pave the way other studies. In this study, the opinions of clients, who were attending the counseling process, were obtained regarding how they experienced the reflecting team method applied during the process. The study was conducted using the interview method, one of the qualitative research methods, with 7 clients who were already attending the counseling process. Most of the clients stated that they had positive feelings about the presence of a reflecting team during the counseling process. The clients expressed that the presence of the reflecting team in the process provided them with multiple perspectives, contributed to their plans for the
\end{abstract}

\footnotetext{
* This paper was presented as an oral paper at the 2nd International Social Sciences Congress held at Nevşehir Hacı Bektaş Veli University between 31 January 2019 and 2 February 2019.

The data of the study were collected between November 2017- December 2017.

Çalışmanın verileri Kasım 2017-Aralık 2017 arasında toplanmıştır.

*** Arş. Gör., Çukurova Üniversitesi, Eğitim Fakültesi, Psikolojik Danışma ve Rehberlik Anabilim Dalı

Res. Asst., Cukurova University, Faculty of Education, Guidance and Counseling Department

ORCID 0000-0002-3347-9965

uzmansumbulyalnizca@gmail.com

**** Dr. Arş. Gör., Çukurova Üniversitesi, Eğitim Fakültesi, Psikolojik Danışma ve Rehberlik Anabilim Dalı

Dr. Res. Asst., Cukurova University, Faculty of Education, Guidance and Counseling Department

ORCID 0000-0003-3472-9716

aycasarac@gmail.com

**** Doktorant, Çukurova Üniversitesi, Eğitim Fakültesi, Psikolojik Danışma ve Rehberlik Anabilim Dalı

Doktorant, Çukurova University, Faculty of Education, Department of Psychological Counseling and Guidance

ORCID 0000-0002-2363-6090

erdinccaglayann@gmail.com

Cite as/ Atıf: Yalnızca Yıldırım, S. Saraç Dengiz, A., Çağlayan, E. (2020). Reflecting team experiences of clients during the counseling process: a post-modernist study, Turkish Studies, 15(2), 1499-1514. https://dx.doi.org/10.29228/TurkishStudies.40311

Received/Geliş: 26 December/Aralık 2019

Accepted/Kabul: 25 April/Nisan 2020

Copyright (C) MDE, Turkey

Checked by plagiarism software

Published/Yayın: 30 April/Nisan 2020

CC BY-NC 4.0
} 
future and enabled the process to focus on 'now and here.' Most of the clients gave a high score to the question 'How effective was the presence of the reflecting team in the counseling session?'; only one client gave it a low score. These findings were discussed in the light of the literature.

Structured Abstract: The purpose of the study was to determine how the clients studied by the reflecting team method experienced this method during the counseling process. Reflecting team practice first emerged as a technique that was used to strengthen the therapeutic process in family and couple therapies (Anderson, 1987), but later, it began to be used as a supervision method. This practice, which is nowadays used in both forms, is applied in the form of an inclusion of one or more therapists except for the therapist in the counseling process and a conversation of those people about the dialogue between the client/family and the therapist in a therapeutic setting (Schlippe \& Schweitzer, 2016; Cox, Banez, Hawley \& Mostade, 2003). Advantages of reflecting team, helps the therapist and the client/family to collaborate and produce new options and meanings for actions (Friedman, Brecher \& Mittelmeier, 1995). On the other hand, the reflective team looks at the client/family's problem from a positive power-oriented perspective and empowers them by focusing on their strengths. It also provides multiple perspectives. Through open, speculative, and respectful dialogues among the reflecting team and their attitudes that do not try to convince each other, the client/family realizes that the problem has multiple solutions (Brownlee et al., 2009).

Research is qualitative. In the study, the interview technique, one of the data collection techniques, was used in the qualitative research. The criterion sampling method was used in the study. Accordingly, the fact that the participants interviewed within the scope of the study were already receiving psychological counseling and volunteered to work with the reflecting team method during the psychological counseling process and to participate in this study was taken as a criterion. In the study, semi-structured interviews were conducted with 7 participants.

The data of this study were collected by the semi-structured interview technique, one of the qualitative data collection methods. The interview form consisting of nine open-ended questions prepared by the researchers was used. In order to ensure the validity, these questions were presented to two domain experts as well as three researchers who carried out the study, and the questions were finalized for the application in line with the opinions and suggestions of the experts. In this study, data analysis was performed by two of the authors. Before coding, both researchers read the questions thoroughly and wrote down the possible codes next to questions. In the second stage, the codes were revised, and an attempt to gather associated codes under certain themes was made. For example, codes such as bonding, active listening, and support were gathered under the theme of counseling skills. In the third stage, the appropriateness of the concepts under certain themes to that theme was revised. In this study, data analysis was performed by the first and third authors of the article. All data were coded separately by both researchers in order to determine the reliability between the researchers. Afterward, consistency between these encodings was calculated. Intercoder reliability was found to be $89 \%$ (Miles \& Huberman, 1994; Yıldırım \& Şimşek, 1999)

As a result of the study, the clients stated that working with multiple therapists at the same time provided them with new perspectives. Moreover, they also indicated that they had a different experience and benefits in this process, that their awareness of their problems and their research motivation were increased, that they wanted to express themselves further, and that their problems were viewed from an objective perspective. In parallel with these results, Smith, Sells, Alves-Perei, Todahl and Papagiannis (1995) indicated that the use of the reflecting team in the counseling process provided clients and the therapist with an alternative perspective for the solution of the problem and enabled clients to talk about their attempts to change before they were demoralized.

Although the clients sometimes felt negative feelings such as tension and confusion, they stated that they generally felt comfortable in the process, were supported by working with more than one therapist and moved away from the feeling of loneliness. Lax (1995) stated that some families/clients find the reflecting team practice confusing and useless. As a result of their studies, Young et al. (1997) determined that hearing and observing the reflecting team led to embarrassment/shame in some clients.

At the end of the study, it was observed that the reflecting team practice was a practice that enriched the counseling process, broadened the clients' perspectives, and made it easier to achieve the goals while dealing with problems. It is necessary to attract attention to existing limitations in order to increase the effectiveness of the practice. One of the limitations of this study was the number of clients. The study was 
carried out with the researchers' clients who were already attending the counseling process, which made the data collection process difficult, and therefore, 7 clients could be interviewed in the study. It is recommended to increase the number of clients interviewed in future studies to be able to get more information about the process. In order to increase the number of clients, it is considered that it will be more appropriate for the researchers to have only reflecting team and interviewer roles, not as counselors, in future studies.

Keywords: Social sciences, Reflecting team, Counseling, Interview, Qualitative study

Öz: Yansıtıcı ekip uygulaması, öncelikle aile ve çift terapilerinde terapötik süreci güçlendirmek için kullanılan bir teknik olarak ortaya çıkmış, ancak daha sonra bir süpervizyon yöntemi olarak kullanılmaya başlanmıştır. Günümüzde her iki haliyle de kullanılan bu uygulama, danışma sürecine terapist haricinde bir ya da daha fazla terapistin dahil olması ve bu kişilerin terapötik bir ortamda danışan/aile ve terapist arasında geçen diyalog ile ilgili konuşmass şekline uygulanır. Alan yazın incelendiğinde dünyada yansıtıcı ekip uygulamasının hem süpervizyon sürecinde hem de terapötik süreç içerisindeki etkisinin birçok araştırmaya konu olduğu görülmektedir. Ancak yansıtıcı ekibin psikolojik danışma sürecinde etkililiği ile ilgili ampirik araştırmalar sınırlı sayıdadır. Yansıııcı ekip tekniğinin danışma sürecindeki etkisini danışan perspektifinden inceleyen bu çalışmanın, Türkiye'de bu konuda yapılacak olan araştırmalara ışık tutacağı düşünülmektedir. $\mathrm{Bu}$ araştırmada, psikolojik danışma sürecine devam eden danışanların, süreçte uygulanan yansıtıcı ekip yöntemini ne şekilde deneyimledikleri ile ilgili görüşleri alınmıştır. Araştırma, araştırmacılarla halihazırda danışma sürecine devam eden 7 danışanla nitel araştırma yöntemlerinden görüşme yöntemi kullanılarak gerçekleştirilmiş̧ir. Danışanların çoğu, danışma sürecinde yansıtıcı ekibin varlı̆̆ı ile ilgili olumlu duygular hissettiklerini ifade etmişlerdir. Danışanlar, yansıtıcı ekibin süreçte bulunmasının onlara çoklu perspektif kazandırdığını, gelecek ile ilgili tasarımlarına katkıda bulunduğunu ve süreci 'şimdi ve burada' ya çektiğini belirtmişlerdir. Yansıtıcı ekibin danışma oturumunda bulunmasının süreçte ne kadar etkili olduğu sorusuna danışanların çoğu yüksek puan vermiş; yalnızca bir danışan düşük puan vermiş̧ir. Elde edilen bu bulgular literatür ışı̆̆ında tartışılmıştır.

Anahtar Kelimeler: Sosyal bilimler, Yansıtıcı ekip, Psikolojik danışma, Görüşme, Nitel araştırma

\section{Introduction}

The conversion of the modern scientific understanding to the postmodern scientific understanding has also led to changes in psychological counseling theories. The role of a psychological counselor, who knows and guides everything, has been replaced by the participantobserver role of a psychological counselor, who can unbalance the structures in the individual expression of the client and create new learning settings during the counseling process (Kogan \& Gale, 1997). Postmodernist psychological counselors almost work as "conversation masters," as described by Anderson and Goolishian (1988). This has enabled the development of new techniques in order to help both counselors and clients. One of these techniques is the reflecting team method.

Reflecting team practice first emerged as a technique that was used to strengthen the therapeutic process in family and couple therapies (Anderson, 1987), but later, it began to be used as a supervision method. This practice, which is nowadays used in both forms, is applied in the form of an inclusion of one or more therapists except for the therapist in the counseling process and a conversation of those people about the dialogue between the client/family and the therapist in a therapeutic setting (Schlippe \& Schweitzer, 2016; Cox et al., 2003).

Reflecting team practice is actually based on the Milan model (Haley, 2002). The major difference between the Milan model and reflecting teamwork is that specialists move to a separate place to develop a hypothesis related to the family and to talk about it in the Milan model. However, in reflecting teamwork, the reflecting team is in the same place with the client and therapist throughout the process, and the client/family hears what the reflecting team thinks about them, and the hypotheses (Haley, 2002). This difference has also brought along some rules that 
should be considered in the process of reflecting team practice. One of them is that the reflecting team does not communicate directly with the client during the dialogue. Furthermore, members of the reflecting team should use expressions that are not too assertive in a way to encourage the client to think and find new ideas instead of questioning his/her own position by using subjunctives rather than imperatives within the framework of respect in conversations between them (Schlippe \& Schweitzer, 2016). Thus, the counselor can also focus on new ideas and solutions without feeling under pressure. In terms of the client, it also enables "talking about the talk" and finding new ideas (Schlippe \& Schweitzer, 2016).

The first stage of the reflecting team process the therapist communicates with the client/family, and the reflecting team listens to them in their place that is separate from the family in the same room. This information gathering stage is a critical process for developing a hypothesis and helping the client/family (Anderson, 1987). In the second stage, the reflecting team is invited to the conversation by the therapist, and the client/family listens (Brownlee, Vis \& McKena, 2009; Cox et al., 2003). In this stage, the reflecting team speaks among themselves to provide family members/the client with alternative ways to become a part of not only the problem but also the solution. In the last stage, after the speech of the reflecting team finishes, the therapist turns the client/family back into the counseling process and talks to the client/family about which ideas of the reflecting team's talks they find useful and which ones they find usable in the future (Brownlee et al., 2009).

Reflecting team practice advantages of reflecting team, helps the therapist and the client/family to collaborate and produce new options and meanings for actions (Friedman, Brecher $\&$ Mittelmeier, 1995). On the other hand, the reflective team looks at the client/family's problem from a positive power-oriented perspective and empowers them by focusing on their strengths. It also provides multiple perspectives. Through open, speculative, and respectful dialogues among the reflecting team and their attitudes that do not try to convince each other, the client/family realizes that the problem has multiple solutions (Brownlee et al., 2009).

The effects of reflecting team practice in the supervision process and in the therapeutic process have been discussed in many studies (Ann-Egeli, Brar, Larsen \& Yohani, 2014; Griffit, 1999; Jenkins, 1996; Lebensohn-Chivalvo, Crago \& Shisslak, 2000; Moran et al., 1995; Morrison, 2009; Çekici, Avcı \& Çolakkadıoglu, 2017). However, there are few empirical studies on the effectiveness of the reflecting team in the counseling process (Brownlee et al., 2009; Willot, Hatton \& Oyebode, 2012). It is considered that this study examining the effect of reflecting team practice on the counseling process from the client's perspective will pave the way other studies.

The purpose of the study was to determine how the clients studied by the reflecting team method experienced this method during the counseling process. Within the framework of this aim, the following sub-aims were determined:

1. To determine how the presence of a reflecting team affected the client's feelings and opinions.

2. To determine to what extent the clients benefited from the reflecting team method.

\section{Method}

\section{Research Design}

The phenomenon science approach, which is one of the qualitative research methods, was used in the research. The phenomenon of science focuses on the cases that are aware but do not have an in-depth and detailed understanding (Yıldırım \& Şimşek, 2013). In this study, the experiences of the clients regarding the reflective team experiences in the psychological counseling process were examined in depth and in detail. 


\section{Participants and Reflective Team}

The study were already receiving counseling and volunteered to work with the reflecting team method during the counseling process and to participate in this study was taken as a criterion. The characteristics of the seven participants can be seen in the Table 1.

Table 1: Characteristics of the Participants

\begin{tabular}{|c|c|c|c|c|}
\hline & Gender & Age & Session & Problem \\
\hline P1 & Female & 33 & 8 & Low life satisfaction, lonelines and negative body image \\
\hline P2 & Male & 23 & 8 & Problems in his romantic relationship ( $\mathrm{K} 3$ is his girlfriend) \\
\hline P3 & Female & 23 & 8 & Problems in her romantic relationship (K3 is her boyfriend) \\
\hline P4 & Female & 22 & 6 & Fear of losing her mind \\
\hline P5 & Female & 21 & 7 & Problems in her romantic relationship \\
\hline P6 & Female & 20 & 7 & Behaviour of pulling her hair \\
\hline P7 & Female & 28 & 4 & $\begin{array}{l}\text { Problems in the relationship of the opposite sex (internal closure, } \\
\text { unable to communicate and conduct) }\end{array}$ \\
\hline
\end{tabular}

Characteristics of the reflecting team formed within the scope of the study, the reflecting team was included in a session of the ongoing counseling processes of 3 researchers who are the authors of this article and each of whom received systemic family therapy training. One of the researchers was a therapist while the other one worked as a reflecting team, and the third researcher conducted an interview with the client after the counseling process. Each of the researchers received Systemic Family Therapy training of 760 units (1 unit=45 minute) from Weinheim Systemic Psychotherapy Institute centered in Germany. The content of 760 units received within the scope of this training is as follows:

- 300-unit theoretical training on average,

- 150-unit self-experience on average,

- 150-unit supervision on average (supervisions also included at least 2 live counselings of a group and each participant with the reflecting team),

- 160-unit vocational training on average conducted with colleagues in the intervention groups, and supervision,

- 200-unit Systemic Therapy sessions on average

- 2-session experience of live counseling (conducting counseling with 2 separate clients accompanied by a reflecting team consisting of a supervisor and 2 colleagues)

- A treatment program detailed in the form of a written thesis

\section{Instruments}

The data of this study were collected by the semi-structured interview technique, one of the qualitative data collection methods. In order to ensure the validity the interview form prepared by the researchers was presented to two domain experts and the questions were finalized in line with the opinions and suggestions of the experts. The data of the study were collected between November 2017- December 2017. The answers of the participants during the interviews conducted alternately by the researchers were recorded by getting the participants' permissions, and then, these interviews were transcribed by the researchers. Interview transcripts are 35 pages. The interviews lasted for a total of 115 minutes. In the interviews conducted, the following questions were asked to the participants:

1. What kind of experience was the presence of the reflecting team in the counseling setting? 
2. How did you feel about the presence of the reflecting team in the counseling setting?

3. What was the most important thing in this session?

4. Was there any negative aspect of the presence of the reflecting team in the counseling setting for you? If so, what was it?

5. In which areas/subjects do you think the presence of the reflecting team in the counseling setting was effective?

6. What was the difference of this session from other sessions according to you?

7. What are your opinions about the presence of the reflecting team in the counseling process?

8. If we were to repeat this counseling process, what would you do differently?

9. If you were to evaluate the effectiveness of this practice, how many points would you rate from 0 to 10 for this session?

\section{Procedure}

Within the scope of the study, the reflecting team was included in a session of the ongoing counseling processes of 3 researchers who are the authors of this article and each of whom received systemic family therapy training. One of the researchers was a therapist while the other one worked as a reflecting team, and the third researcher conducted an interview with the client after the counseling process. At first, attention was paid to the fact that the counselor would realize that there was a need for such a practice both for him and the client in the process while determining the clients to whom reflecting team practice would be applied. After the client approves the reflecting team practice, the person involved in the reflecting team is informed about the previous sessions conducted with the client. The counseling process starts after the reflecting team is introduced to the client. At the beginning of the counseling process, the counselor initiates the counseling process byrepeating the explanations regarding the reasons for the inclusion of the reflecting team in the process and the conditions for their inclusion. The counselor states that "he also wonders about the reflecting team's opinion in this regard" in any part of the process, then he turns to the reflecting team and allows them to express their ideas and hypotheses. After the counseling process is terminated, the other researcher gets into the room to have an interview with the client and asksthe questions determined within the scope of the study.

\section{Ethical consideration}

A consent form was signed by all participants to participate in the study.

\section{Data Analysis}

The content analysis method was used in the analysis of the data obtained as a result of the interview. The data obtained in the content analysis method are summarized and interpreted according to the predetermined themes. In this method, the data can be determined according to the themes revealed by the research questions, as well as the questions or dimensions used in the interview and observation processes (Yıldırım \& Şimşek, 2013). In this study, data analysis was performed by two of the authors. Before coding, both researchers read the questions thoroughly and wrote down the possible codes next to questions. In the second stage, the codes were revised, and an attempt to gather associated codes under certain themes was made. For example, codes such as bonding, active listening, and support were gathered under the theme of counseling skills. In the third stage, the appropriateness of the concepts under certain themes to that theme was revised. In this study, data analysis was performed by the first and third authors of the article. All data were coded separately by both researchers in order to determine the reliability between the researchers. 
Afterward, consistency between these encodings was calculated. Intercoder reliability was found to be $89 \%$ (Miles \& Huberman, 1994; Y1ldırım \& Şimşek, 2013)

\section{Result}

Client's experiences regarding the presence of the reflecting team in the counseling setting information about the client's experiences during the counseling session in which the reflecting team was involved is presented in Table 2.

Table 2: Consultant Experiences of Reflective Team in Consultation

\begin{tabular}{llc}
\hline Category & Themes & Frequency (f) \\
\hline & Multiple perspectives & 5 \\
& Cooperation among therapist (supervision) & 4 \\
Effect of reflective team & Different experiences & 2 \\
& Research motivation & 2 \\
& Awareness & 1 \\
& Objective perspective & 1 \\
& Desire for self-expression & 1 \\
& Benefit & 1 \\
\hline
\end{tabular}

As it is seen in Table 2, the clients mainly emphasized the cooperation among therapists $(\mathrm{f}=4)$ and gaining multiple perspectives $(\mathrm{f}=5)$ with respect to the effect of the reflecting team. Moreover, they also stated that the reflecting team had effects such as ensuring research motivation $(\mathrm{f}=2)$, providing different experiences $(\mathrm{f}=2)$, providing an objective perspective $(\mathrm{f}=1)$, raising awareness $(\mathrm{f}=1)$, creating a desire for self-expression $(\mathrm{f}=1)$, and feeling benefit $(\mathrm{f}=1)$.

The statement of one of the clients who emphasized the cooperation of the therapist with respect to the effect of the reflecting team is presented below:

"My counselor has known us for 7 sessions, and maybe she may create something about us in her mind. Well, right now, maybe she has probably become interwoven with us. However, Mr. Erdinç is a completely external eye. Well, to the extent to be able to see the mistakes of Mrs. Ayça. A human who looks over and can say that Ayça made a mistake here and those people are like this because it is a completely external eye." (P6)

\section{Clients' feelings about the presence of the reflecting team in the counseling setting}

Clients' feelings about the presence of the reflecting team in the counseling setting are presented in Table 3.

Table 3: Clients' Feelings of Reflective Team in Consultation

\begin{tabular}{ccc}
\hline Categories & Themes & Frequency $(\mathbf{f})$ \\
\hline Positive Feelings & Pleased & 7 \\
& Feelings of comfort & 3 \\
& Being understood & 2 \\
& Excitement & 1 \\
\hline Negative Feelings & Displeasure & 2 \\
& Anger & 1 \\
& Anxiety & 1 \\
\hline
\end{tabular}

When Table 3 was examined, the clients expressed positive and negative feelings about the presence of the reflecting team in the session. All of the clients expressed that they were pleased with the presence of the reflecting team in the session. Moreover, the feelings of $\operatorname{comfort}(\mathrm{f}=3)$, 
excitement $(\mathrm{f}=1)$ and being understood $(\mathrm{f}=2)$ related to the session were also expressed by the clients. The themes emerging in the negative feelings category were anger $(\mathrm{f}=2)$, anxiety $(\mathrm{f}=1)$, and displeasure $(\mathrm{f}=1)$.

The statements of two of the clients who stated that they felt being understood and displeased in the process are presented below:

"We are always in a cycle; we always quarrel. We are trying to get each other to accept something. Mr. Erdinç also said that you are always in a cycle. Well, so, I don't believe that you are lying. Or, I mean, I do not think whether you are correct or not." (P3)

“...I do not know how I can express it. I liked that a different person next to me took notes.” (P1)

\section{The most important thing in the session with the presence of the reflecting team}

The clients expressed the themes in Table 4 on what was the most important thing in the session with the presence of the reflecting team.

Table 4: The Most Important Thing in a Reflective Team Session

\begin{tabular}{ccc}
\hline Categories & Themes & Frequency (f) \\
\hline \multirow{3}{*}{ Related to clients } & Awareness of problems & 3 \\
& Personal awareness & 2 \\
& Dissappointment & 1 \\
& Self-expression & 1 \\
\hline Related to therapists & Encouraging & 2 \\
& Bonding & 1 \\
& Questions & 1 \\
& Re-framing & 1 \\
\hline
\end{tabular}

In Table 4, the clients found most important in the counseling session attended by the reflecting team were divided into two: those related to clients and those related to therapists. The points that the clients stated as most important for themselves were gaining awareness of problems $(\mathrm{f}=3)$, gaining personal awareness $(\mathrm{f}=2)$, disappointment $(\mathrm{f}=1)$, and self-expression $(\mathrm{f}=1)$. With respect to therapists, the participants emphasized the use of counseling skills such as encouraging $(\mathrm{f}=1)$, bonding $(\mathrm{f}=1)$, asking questions $(\mathrm{f}=1)$, and re-framing $(\mathrm{f}=1)$. are as follows:

The statements of the clients related to gaining awareness of problems and encouragement

"This was important for me. I mean, you have clearly told me what I need to discover. So, I got this message exceedingly. I also said that I would do some research. Clarity was good for me in this session, it was clear." (P4)

"I was hiding myself, building walls. And that's why I thought I was a coward. However, I liked that you came to me and told me that I was actually a courageous client for my selfdisclosure, and I got it right away and tagged myself. I mean, just at that moment. I said yes, I am courageous." (P6)

\section{Negative aspects of the presence of the reflecting team in the counseling setting}

Almost all of the clients $(\mathrm{f}=5)$ stated that the presence of the reflecting team in the counseling setting has no negatice aspect and they found itrelaxing and useful. A small number of the clients $(\mathrm{f}=2)$ who found the presence of the reflecting team in the session disturbing indicated that they were disturbed by the note-taking of the reflecting team and experienced uneasiness, 
anxiety of being evaluated, alienation, and fear of confrontation in the process with the presence of the reflecting team.

The statements of one of the clients who indicated that there was no negative aspect of the presence of the reflecting team in the process and that they were disturbed by the presence of the reflecting team are presented below:

"Me, anything negative, I mean there was certainly no something to disturb me. On the contrary, I felt good."(P2)

"Negative effect ... Normally, my counselor was not taking notes. I lost my desire a bit more since the counselor took notes. It seemed as if someone was spying on us. That's all ..." (P1)

Areas/subjects in which the presence of the reflecting team in the counseling setting was effective

The answers of the clients to the question about the areas in which the presence of the reflecting team in the counseling setting was effective are presented in Table 5.

Table 5: Areas/Subjects in Which the Presence of the Reflecting Team in the Counseling Setting Was Effective

\begin{tabular}{ccc}
\hline Categories & Themes & Frequency (f) \\
\hline \multirow{2}{*}{ Related to the counseling process } & Multiple perspectives & 4 \\
& Clarifying the process & 1 \\
& Here and now & 1 \\
& Questions & 1 \\
\hline \multirow{2}{*}{ Related to client experiences } & Plans for the future & 2 \\
& Personal awareness & 1 \\
& Re-framing & 1 \\
\hline
\end{tabular}

In Table 5, it appears that the effects of the presence of the reflecting team in the counseling setting were divided into two as the effects related to the counseling process and the effects related to client experiences.

The fact that the presence of the reflecting team provided the process with multiple perspectives $(\mathrm{f}=4)$ was the most expressed effect among the effects related to the counseling process. Moreover, it was also stated that the presence of the reflecting team was effective with respect to clarifying the process $(\mathrm{f}=1)$, enabling the process to focus on ' here and now, $(\mathrm{f}=1)$ and asking effective questions $(\mathrm{f}=1)$. The opinions of one of the clients who stated that they gained multiple perspectives are presented below:

"I mean, the fact that you see the points that the client cannot see, that you grasp the things that he can't see in himself. You know, your approach to me from a different perspective made me look at myself from a different perspective." (P6)

With respect to client experiences, the clients emphasized that the reflecting team contributed in terms of providing plans for the future, gaining personal awareness, and re-framing. The statements of one of the clients who indicated that they acquired information about the plans for the future are as follows.

"For instance, you say: where do you see yourself in 5 years. You have asked what my ideal is ..." (P7) 


\section{The difference of this session from other sessions}

The participants' answers related to the difference of this session from other sessions are presented in Table 6.

Table 6: The Difference of This Session From Other Sessions

\begin{tabular}{ccc}
\hline Category & Themes & Frequency (f) \\
\hline \multirow{3}{*}{ Related to clients } & Self-expression & 2 \\
& Feeling not alone & 1 \\
& Transfer to life & 1 \\
& Fear of confrontation & 1 \\
& Personal awareness & 1 \\
\hline Related to the counseling process & Multiple perspectives & 4 \\
& Cooperation among therapist (supervision) & 1 \\
& Here and now & 1 \\
& Cyclical communication & 1 \\
\hline
\end{tabular}

When Table 6 was examined, it appeared that the difference of the session with the reflecting team from other sessions was divided into two as the differences related to clients and the differences related to the counseling process.

With respect to the differences related to clients, the clients indicated that they felt they were not alone in this session $(\mathrm{f}=1)$, could express themselves $(\mathrm{f}=2)$, thought they could transfer what was spoken in this session to $\operatorname{life}(\mathrm{f}=1)$, feared to face the aspects they did not want to see $(\mathrm{f}=1)$, and gained personal awareness $(\mathrm{f}=1)$. The statements of one of the clients who indicated that they gained personal awareness are presented below:

"For instance, I talked to a table. I do not talk to non-living things a lot. What the table would say to me increased my insight." (P6).

With respect to the counseling process, the clients mostly stated that they gained multiple perspectives $(\mathrm{f}=4)$. Furthermore, cooperation among therapists $(\mathrm{f}=1)$, enabling the process to focus on here and now $(f=1)$, cyclical communication $(f=1)$, and tense atmosphere $(f=1)$ were also expressed by a small number of participants. The statements of the client who indicated that he had a fear of confrontation are presented below:

"...I mean, as I said, I also felt fear at first. The fear of being tried or hearing the facts. I also felt it. Then it disappeared." (P4)

\section{Clients' opinions about the presence of the reflecting team in the counseling process}

Clients' opinions about the presence of the reflecting team in the counseling process are presented in Table 7.

Table 7: Clients' Opinions About the Presence of the Reflecting Team in the Counseling Process

\begin{tabular}{ccc}
\hline Categories & Themes & Frequency (f) \\
\hline Positive feelings and opinions & Pleased & 2 \\
& Professional confidence & 1 \\
& Benefit & 1 \\
& Multiple perspectives & 1 \\
\hline Negative feelings and opinions & Displeasent & 1 \\
& Uneasiness & 1 \\
& Confusion & 1 \\
\hline
\end{tabular}

Turkish Studies, 15(2) 
When Table 7 was examined, it appeared that the clients talked about their feelings as well as their opinions about the presence of the reflecting team in the counseling session. The statements expressed by the clients were divided into two as positive feelings and opinions and negative feelings and opinions. It was remarkable that feelings mainly emerged, although opinions were asked in this category.

In the positive feelings and opinions, the clients stated that they were pleased( $\mathrm{f}=2)$, had professional confidence in their therapists $(\mathrm{f}=1)$, provided benefits $(\mathrm{f}=1)$, and gained multiple perspectives $(\mathrm{f}=1)$. The statements of one of the clients who indicated satisfaction are presented below:

"Namely, it was a good environment for me. It was an environment I enjoyed." (P7)

In the negative feelings and opinions, the clients stated that they were displeased( $\mathrm{f}=1)$, felt uneasiness $(\mathrm{f}=1)$, and were confusied $(\mathrm{f}=1)$. The statements of the client who indicated dissatisfaction are presented below:

"The fact that he was behind me was something like..., for instance, I said, "I wish he would next to me," I mean, I thought of something like that related to Mr. Erdinç. It became a little bit difficult for me to turn and look." (P2)

The things that the clients would do differently in the case of the repetition of the counseling process conducted with the reflecting team

The clients' answers to the question of what the clients would do differently in the case of the repetition of the counseling process conducted with the reflecting team are presented in Table 8 .

Table 8: The Things That the Clients Would Do Differently in the Case of the Repetition of the

Counseling Process Conducted with the Reflecting Team

\begin{tabular}{ccc}
\hline Categories & Themes & Frequency (f) \\
\hline Related to therapist & Not taking notes & 1 \\
& Warn about the confrontation & 1 \\
\hline \multirow{3}{*}{ Related to clients } & Not crying & 1 \\
& Less self-disclosure & 1 \\
\hline I wouldn't do anything & Not interrupting the partner & 1 \\
different & & 4 \\
\hline
\end{tabular}

When Table 8 was examined, it appeared that most of the clients stated that they would not do anything differently if the session with the reflecting team was repeated. Furthermore, the areas in which the clients wanted to make a difference were divided into two as those related to therapists and the client.

In the section related to therapists, the clients indicated that they would not make the reflecting team take notes $(\mathrm{f}=1)$ and would warn about the confrontation in the case of the repetition of the process $(\mathrm{f}=1)$. The statements of the client who talked about warning with regard to confrontation are presented below:

"I would prefer that the questions would be a little softer, well, I mean, without holding against the opposite party, they would be asked without hitting them." (P1)

In the section related to the client, the clients stated that they would employ the behaviors of not crying $(\mathrm{f}=1)$, less self-disclosure $(\mathrm{f}=1)$, and not interrupting the partner $(\mathrm{f}=1)$. The statements of the client about not crying are presented below: 
"Let me think about what I would do differently. I would not cry." (P2)

\section{Effectiveness of the reflecting team practice}

The clients were asked to rate the effectiveness of the reflecting team practice between 1 and 10. Only P1 gave "1" point to the effectiveness of the process. Although the client stated that he gave 8 points verbally, he pointed 1 point with his hand. Therefore, his scoring was considered as "1." The other six clients found the counseling process effective and scored between 8-10.

The statements of one of the participants who gave 10 points by considering that the process was completely effective are presented below:

"Because, ultimately, it managed to mobilize me. I have never thought about getting out of counseling and doing research. Therefore, I think it has effectiveness. So, I think, go ahead." (P4)

\section{Discussion and Conclusion}

The clients included in the study compared the reflecting team practice with their revious counseling processes and stated that their experiences with this practice were different compared to other counseling processes. According to Haley (2002), in traditional approaches, there is a numb therapist on the therapy chair and a client who has been lost in his own history, and they need a new, different and surprising approach. In reflective team approach, there is an energetic and professional team working cooperatively to solve the problems of clients. This team is involved in the counseling process, emphasizes the strengths of clients, and tries to mobilize them for change. In such a setting, it becomes easier for clients to become free and to manifest themselves honestly and clearly (Perlesz, Young, Paterson \& Bridge, 1994; Haley, 2002). In this study, it was observed that the clients had no difficulty in sharing private experiences about themselves while they were together with the reflecting team, that they felt that they were understood and supported and that their motivation to work with them increased and thus they gained awareness of both their problems and themselves. This awareness also included the connections established with real life and the future. From this information, it can be said that the reflective team practice mentioned in the psychological counseling was beneficial for the beneficial and use of the client and the consultant data. From this information, it can be said that the reflective team practice mentioned in the psychological counseling was beneficial for the beneficial and use of the client and the consultant data. This practice, which has been shown to be useful with empirical findings, even in a limited number. In order to become widespread in the field of psychological counseling, It is thought that providing training to practitioners can offer a significant benefit to the field. Increasing scientific studies on practice can also contribute to the field in the recognition, learning and adoption of reflective team intervention.

As a result of the study, the clients stated that working with multiple therapists at the same time provided them with new perspectives. Moreover, they also indicated that they had a different experience and benefits in this process, that their awareness of their problems and their research motivation were increased, that they wanted to express themselves further, and that their problems were viewed from an objective perspective. In parallel with these results, Smith et al. (1995) indicated that the use of the reflecting team in the counseling process provided clients and the therapist with an alternative perspective for the solution of the problem and enabled clients to talk about their attempts to change before they were demoralized. Pare (1999) stated that the understanding of multiple perspectives was adopted in reflecting team practices, that interpretation was important while deciding on what was right for clients, and that the diversity of these interpretations would increase the effectiveness of the counseling. Cox et al. (2003) stated that the presence of the reflecting team provided the client with a supportive and cooperative environment that made the client feel that he was understood and heard instead of making diagnosis. 
In the light of the information presented above, it can be said that the results of this study are similar to the limited number of research findings on the subject. Clients have gained new awareness through different perspectives on their problems brought to the consultation process, they appear to emphasize that they are supported and understood, and this information provides some previously highlighted information about the functionality of the reflective team application. Regardless of the theoretical approach that the counselor has, all the psychological counseling aims are to bring the counselors to the cause of the reasons for coming to the counseling. In the process of achieving these goals, it is stated as some duties of the advisors to give the clients some awareness about their lives, enrich their intellectual-emotional worlds from different perspectives, start thinking about their lives and act with a sense of responsibility (Egan, 2013). Considering the benefits of the reflective team practice, it can also be argued that it is a functional practice to achieve the tasks in the above-mentioned consultation process. It can also be said that this application, which is a supportive aspect for the therapeutic relationship, which is considered as one of the most important healing factors of the psychological counseling process, is beneficial for the client and counselor to establish an egalitarian relationship based on cooperation and trust and away from the expert attitude (Haley, 2002).

Although the clients sometimes felt negative feelings such as tension and confusion, they stated that they generally felt comfortable in the process, were supported by working with more than one therapist and moved away from the feeling of loneliness. These negative emotions can be reduced by the therapist and the reflective team giving encouraging feedback. But it should not be overlooked that there should be some anxiety for change in counseling (Yalom, 2003). Lax (1995) stated that some families/clients find the reflecting team practice confusing and useless. As a result of their studies, Young et al. (1997) determined that hearing and observing the reflecting team led to embarrassment/shame in some clients. Dallos and Draper (2012) indicated that the different possible explanations of the reflecting team led to a contrast, disturbed clients, stimulated them, increased their creativity, and made them feel better about their own ideas that were incompatible with society. Furthermore, in the same report, the researchers also emphasized that different perspectives and contrasts might play a facilitating role in internalizing what was spoken in the counseling process. The clients included in the study talked about the discomfort that they felt at the beginning of the process and that disappeared during the process. This can be interpreted as the emergence of a negative feeling that is necessary for change and has short-term effects.

The clients considered that the process was effective and expressed their satisfaction during their assessment of the process. In a similar study carried out by Anslow (2013), most of the participant found the process efficient and provided feedback that it could be repeated. In another qualitative study carried out by Ann-Egeli et al. (2014) to investigate the effect of reflecting team practice on the counseling process, clients indicated that they considered that they made progress in the session, that their hopes for well-being increased, and that they found this technique effective.

At the end of the study, it was observed that the reflecting team practice was a practice that enriched the counseling process, broadened the clients' perspectives, and made it easier to achieve the goals while dealing with problems. It is necessary to attract attention to existing limitations in order to increase the effectiveness of the practice. One of the limitations of this study was the number of clients. The study was carried out with the researchers' clients who were already attending the counseling process, which made the data collection process difficult, and therefore, 7 clients could be interviewed in the study. It is recommended to increase the number of clients interviewed in future studies to be able to get more information about the process. In order to increase the number of clients, it is considered that it will be more appropriate for the researchers to have only reflecting team and interviewer roles, not as counselors, in future studies. 
However, in this study, all clients except P2 and P3 who were in the process of psychological counseling requested individual counseling. In the future studies, as Anderson (1987) emphasizes, the benefits of working with families can be tested in the reflective team practice, which has emerged as a technique used primarily to strengthen the therapeutic process in family and couple therapies. In addition, as an alternative to revealing the opinions of the clients about the effectiveness of the reflective team practice with the qualitative method, the development of standard measurement tools can contribute to the literature to reveal the opinions about the usefulness of this application. Particularly in universities, individuals who are trained in order to specialize in the field of Psychological Counseling can be included in the educational processes of the reflective team practice, theoretically and practically, and the candidates of psychological counselors can be provided with knowledge and skills in this regard.

Within the scope of this research, the reflective team, the consultant and the therapist who were included in the reflective team were formed. Because it was thought that it would not be ethical if the researcher who met with the client at the end of the counseling session was in the reflective team. It is considered that it would be appropriate to increase the number of professionals included in the reflecting team in future studies. Furthermore, in this study, the process involving the reflecting team was the individual psychological counseling process (there was 1 couple). The current study can be repeated in the counseling processes conducted with families and couples. In this way, detailed information about the effects of the reflective team process on different members of the family can be obtained. In addition it can be determined whether this approach, which is based on family therapies, is suitable for Turkish families. In this study, the reflecting team was involved in only one session of the counseling process, and the interviews were conducted immediately after that session. In future studies, interviews can be conducted again with clients who continue to attend the counseling process. Thus, the effect of the reflecting team in the process can be investigated. Moreover, the effects of the participation of the reflecting team in more than one session in ongoing counseling processes can also be investigated. In this study, interviews were conducted only with the clients. However, in future studies, therapists can also be interviewed for more detailed determination of the reflecting team's effects on the counseling process.

\section{References}

Anderson, T. (1987). The reflecting team: Dialogue and meta-dialogue in clinical work. Family Process Journal, 26, 415-428

Anderson, H., \& Goolishian, H. A. (1988). Human systems as linguistic systems: Preliminary and evolving ideas about the implications for clinical theory. Family process, 27(4), 371-393.

Ann-Egeli, N., Brar, N., Larsen, D., \& Yohani, S. (2014). Coules experiences of hope when participating in the reflective team process: A case study. Contemporary Family Therapy, 36, 93-107.

Anslow, K. (2013). Systemic family therapy using the reflecting team: the experiences of adults with learning disabilities. British Journal of Learning Disabilities, 42(3), 236-243.

Brownlee, K. Vis J., \& McKenna, A. (2009). Review of reflective team process: Strenghts, challenges and clinical implications. The Family Journal: Counseling and Therapy for Copules and Families, 17(2), 139-145.

Cox, J. A., Banez, L., Hawley, L. D., \& Mostade, J. (2003). Use of reflective team process in the training of group workers. Journal for Specialists in Group Work, 28(2), 89-105. 
Çekici, F., Avcı, R. \& Çolakkadıŏlu, O. (2017). Psikolojik danışmada post-modernist bir süpervizyon yöntemi: Yansitıc1 ekip uygulaması. Turkish Studies, 12(28), 175-192.

Dallos, R., \& Draper, R. (2012). Aile terapisine giriş. Ankara: Nobel Yayıncılık.

Egan, G. (2013). Psikolojik Danışma Becerileri (çev. Ö. Yüksel). İstanbul: Kaknüs Yayınları

Friedman, S., Brecher, S., \& Mittelmeier, C. (1995). Widening the lens, sharpening the focus: The reflecting process in managed care. In S. Friedman (Ed.), The reflecting team in action: Collaborative practice in family therapy (s. 184-204). New York: Guilford Press.

Griffith, W. (1999).The reflective team as an alternative case teaching model: A narrative, conversational approach. Management Learning, 30(3), 343-362.

Haley, T. (2002). The fit between reflecting teams and a social constructionist approach. Journal of Systemic Therapies, 21(1), 20-40.

Jenkins, D. (1996). The reflective team approach to family therapy: A Delphi study. Journal of Marital and Family Therapy, 22(2), 219-238.

Kogan, S. M., \& Gale, J. E. (1997). Decentering therapy: textual analysis of a narrative therapy session. Family Process, 36, 101-126.

Lax, W. D. (1995). Offering reflections: Some Theoretical and practical considerations. In S. Friedman (Ed.), The reflecting team in action: Collaborative practical in family therapy (p.p. 145-166). New York: Guildford Press

Lebensohn-Chivalvo, P., Crago, M., \& Shisslak, C.M. (2000). The reflective team: An innovative approach for teaching clinical skills to family practice residents. Residency Education, 32(8), 556-560.

Miles, M. B., \& Huberman, A. M. (1994). An Expanded Sourcebook of Qualitative Data Analysis (2 . bask1). London: Sage Publication.

Moran, A., Brownlee, K., Gallant, P., Meyers, L., Farmer F., \& Taylor, S. (1995). The effectiveness of reflective team supervision: a client's experience of receiving feedback from distance. Family Therapy, 22(1), 31-47.

Morrison, P. A. (2009). Using an adapted reflective team approach the learn about mental health and illness with general nursing students: an Australian examples. International Journal of Mental Health Nursing, 18, 18-25.

Pare, D.A. (1999). Using reflecting teams in clinical training. Canadian Journal of Counseling, 33, 293-306.

Perlesz, A., Young, J., Paterson, R., \& Bridge, S. (1994). The reflecting team as a reflection of second order therapeutic ideals. Australian and New Zealand Journal of Family Therapy, 15(3), 117-127.

Schlippe, A., \& Schweitzer, J. (2016). Sistemik Müdahaleler (çev. T. Akbaş, B. Bozoğlan ve E. Yıldizeli). Ankara: Pegem Akademi. (Orijinal yayın tarihi:2010).

Smith, T. E., Sells, S.P., Alves-Pereira, G., Todahl, J., \& Papagiannis, G. (1995). Pilot process research of reflecting conversations. Journal of Family Psychotherapy, 6, 71-89.

Willot, S., Hatton, T., \& Oyebode, J. (2012). Reflective team process in family therapy: a search for research. Journal of Family Therapy, 34, 180-203. 
Yalom, I. (2003). Kısa Süreli Grup Terapileri (çev. Zeliha İyidoğan Babayiğit). İstanbul: Kabalcı Yayınevi. (Orijinal yayın tarihi: 1983).

Yıldırım, A. \& Şimşek, H. (2013). Sosyal Bilimlerde Nitel araştırma Yöntemleri. İstanbul: Seçkin Yayıncilik.

Young, J., Saunders, F. Prentice, G., Macri-Riseley, D., Fitch, R. \& Pati-Tasca, C. (1997). Three Journeys toward the reflecting team. Australian and New Zealand Journal of Family Therapy, 18, 27-37. 